\title{
The emergence of 'cultural heritage' in modern China: a historical and legal perspective
}

\author{
Guolong Lai \\ University of Florida
}

\section{Introduction}

In the fall of 1924, the pre-eminent modern Chinese scholar Wang Guowei 王國維 (1877-1927) wrote a long acrimonious letter to Shen Jianshi 沈兼士 (1885-1947) and Ma Heng 馬 衡 (1880-1955), directors of the National Beijing University's Department of Chinese Classics (guoxuemen 國學門) and its archaeology program. The letter came in response to a 'Manifesto

How to cite this book chapter:

Lai, G 2016 The emergence of 'cultural heritage' in modern China: a historical and legal perspective. In: Matsuda, A and Mengoni, L E (eds.) Reconsidering Cultural Heritage in East Asia, Pp. 47-85. London: Ubiquity Press. DOI: http://dx.doi.org/10.5334/baz.d. License: CC-BY 4.0 
for the Preservation of the Ancient Site at Dagongshan' (Baocun Dagongshan guji xuanyan 保存大宮山古蹟宣言) by the University's Archaeological Society, which Wang Guowei had just seen printed in a newspaper (Lui, \& Yuan 1984: 405-407; Yuan \& Lui 1996: 431-433; see also Bonner 1986: 202-204). The manifesto deplored a Manchu prince's destruction of the 'state property' (guanchan 官產) at Dagongshan in the Dajue 大覺 temple, in the western suburbs of Beijing. It went on to accuse the abdicated Last Emperor Puyi 溥儀 (1906-1967), who was still living in the back quarter of the Forbidden City, of having 'taken ancient artefacts (guqiwu 古器物) handed down through the ages as his personal property', and called on the Chinese people and the Nationalist government to stop the destruction of national heritage.

Encouraged by another conservative loyalist, Luo Zhenyu 羅 振玉 (1866-1940), Wang Guowei argued, against the Manifesto, that the legal status of the site that the Manchu prince had allegedly destroyed was uncertain. More importantly, he asserted that the imperial collections had been historically accumulated by the Manchu emperors, and that:

'every object in the imperial palace in addition to those exhibited in the Wenhua and Wuying palaces [in the front part of the Forbidden City], before the Republic compensated the imperial family, under any laws, ancient or modern, Chinese or foreign, is the private property (sichan 私產) of the imperial family'.

He continued:

'This is also so stipulated in the Republic's own legal document, "The Articles of Favourable Treatment of the Great Qing Emperor after His Abdication", which has been under the protection of law and recognized by successive regimes'. 
In this letter, Wang declared his resignation from his position at the National Beijing University, severed any connection with the University, and withdrew an article scheduled to be published in the University's journal.

Wang Guowei acutely noted that the real issue at stake was the fate of the imperial collections and the Last Emperor's personal property rights. He was partially right in arguing that in Chinese dynastic history, at least institutionally, the imperial household and the state had distinct budgets and separate finances. Thus, in theory at least, the imperial family's collections and property could be considered as 'private property' under the modern Westernized legal system that the Republic of China had adopted. In fact, as Wang rightfully pointed out, the Republic's 'Articles of Favourable Treatment' (article 7) guaranteed the Last Emperor's rights in this regard.

However, one could argue, and this seems to have been the opinion of the majority at the time, that the uses and abuses of imperial power often blurred the distinction between the imperial household and the state finances. By insisting on this distinction, Wang took a conservative, legalistic, and somewhat unworldly approach. But for most citizens of the new Republic of China, including many scholars and intellectuals, this distinction had become meaningless. To them, the imperial collections were the essence of the 5,000-year old Chinese civilization, in which the 'spirit of the [Chinese] nation' (liguo jingshen 立國精神) reposed (jituo 寄托). ${ }^{1}$ But why and how could the collections of a fallen Manchu dynasty represent the spirit of a new nation? What other objects and sites could be deemed as 'national heritage'? Why and how did they emerge as national 'cultural heritage'?

In this chapter I try to answer these questions by tracing the evolution of 'cultural heritage' and other related concepts in modern 
China from a historical and legal perspective. The Chinese term now used to refer to a nation's or people's heritage from the past, 'wenhua yichan', 文化遺產, a direct translation of the English term 'cultural heritage', is a neologism that has become popular in Chinese writings only since the 1980s. ${ }^{2}$ But similar concepts, such as 'guwu'古物 (ancient objects), 'shiji'史跡 (historic sites), 'guji' 古跡 (ancient sites), 'mingsheng'名勝 (famous sights), 'wenwu' 文物 (cultural relics), and 'guobao' 國寶 (national treasures), began to be used right at the inception of modern China, and this was also when the practice of heritage preservation was instituted.

As a national cultural policy, heritage preservation was introduced into China from the West as part of the modernizing efforts under the late Qing dynasty. In fact, the very concept of 'national heritage' emerged with modernity, which in turn compelled the changes in how cultural heritage was conceived and what measures were taken to conserve it. In what follows, I focus on two legislative documents on cultural heritage from the first three decades of the 20th-century. The first document is the 'Measures for the Protection of Ancient Sites (Baocun guji tuiguang banfa zhangcheng 保存古跡推廣辦法章程)' that the Qing government issued in 1909. This is the earliest known Chinese governmental ordinance on the protection of cultural heritage that we know. The second is the 'Law on the Preservation of Ancient Objects (Guwu baocun fa 古物保存法)', issued by the Nationalist government in 1930. These two documents set up the basic legal framework for the protection of cultural heritage in modern China. ${ }^{3}$

Among the different levels of social awareness, the state legislation is the most structured, enduring, and prominent expression of the collective attitude toward the past. By examining the process by which the state's legislative framework came into being, we can see the impact of old practices on heritage 
preservation in modern China, as well as the introduction of new approaches.

As is well known, the practice of collecting art objects and preserving places with religious or political significance certainly had a long tradition in imperial China. These practices, however, did not lead to a full public and national policy until the end of the 19th-century. Some scholars have argued that, in pre-modern China, precious artefacts, paintings, calligraphic works, bronzes, and so forth, were generally in imperial or private collections; and temples, palaces, and other architectural complexes were in the hands of private owners, religious orders, or the imperial court. These scholars maintain that there was virtually no state ownership of cultural property (see Naquin 2000: xxviii-xxx). Others may disagree. But the modern state stewardship of cultural heritage is often - especially in non-Western developing countries based firmly on the notion of public ownership. In modern China, as in many other modern nations, the rise of public awareness and the protection of heritage through legislation went along with the building of the modern nation state. Among the art treasures, artefacts, monuments, and sites first declared as 'national heritage' were the imperial collections and property, deserted ancient sites, and archaeologically excavated artefacts.

\section{Educational reform and the introduction of new values}

The military and cultural conflicts with the West and Japan in the late 19th-century caused Chinese people collectively to reevaluate the past. Additionally, by the late 19th-century, China had already embarked, however tentatively and unwillingly, on a new path to modernization and reform, which inevitably 
undermined traditional ways of valuing the past. The impetus for change emerged from both inside and outside China, but it was the external threats and demands for changes that were to prove to be the more effective catalysts for change.

As a result of the Opium War (1839-1842), the military superiority of the Western powers became the hard truth confronting many Chinese scholars and officials. High officials, such as Zeng Guofan 曾國藩 (1811-1872) and Li Hongzhang 李鴻章 (1823-1901), following their advisors Wei Yuan 魏源 (1794-1856) and Feng Guifen 馮桂芬 (1809-1874), had responded to this revelation by attempting to reform the military and thereby to strengthen China's ability to achieve balance with the West. This includes building arsenals to produce modern weaponry, establishing military schools to train officers, setting up translation schools and institutions to introduce Western knowledge, and sending young students abroad to study military techniques and navigation. The spirit of this so-called 'self-strengthening movement' could be summarized in Zhang Zhidong's (1837-1909) words, 'Chinese learning for essence, Western learning for application' (Zhongxue wei ti, xixue wei yong 中學為體, 西學為用). ${ }^{4}$

However, for a few scholar-officials - such as Guo Songtao 郭嵪 壽 (1818-1891), who had been a diplomat in Britain - this 'selfstrengthening movement' did not go far enough. These scholars recognized that the weakness of the Qing government and the strength of the Western powers could not be evened out merely by the acquisition of military hardware and technological knowhow; what was necessary, instead, was the reformation of political and social institutions and cultural values (Wang 2006). After China's disastrous defeat in the Sino-Japanese War of 1895, an increasing number of scholar-officials started to call for more thoroughgoing reforms, especially in the political and institutional realms. 
Observing the Western practice of the expansion of public institutions in the modernization process, Guo was among the first group of Chinese intellectuals to advocate for the development of public institutions in China; even making an effort to build a public museum (Hu 2000).

Although the Qing court was initially reluctant to change, the Boxer Rebellion in 1900 increased both internal and external pressures, prompting the Empress Dowager Cixi (1835-1908) to issue a reform decree. The policies spelled out therein continued to be implemented throughout the first decade of the 20th-century. This was the Manchu Qing dynasty's final attempt to implement a series of educational, military, and economic reforms in order to modernize China and to strengthen the nation in its military and financial power. Although most of these reforms proved ineffective, they did accelerate the introduction of new social values and the formation of new elites (Wakeman 1975: 228).

In September 1905, the civil service examinations were abolished, and in December, the Ministry of Education was established as the central organ for late Qing educational administration (Guan 2000). The educational reform challenged the role of Confucianism as the state ideology. The Confucian classics had long been used as the basis for written examinations in recruiting young scholars to the administrative service of the imperial state. Even under the new system, the Qing government still attempted to reinforce traditional Confucianism. For example, the regulations concerning educational institutions approved by the Emperor required that on the first and fifteenth days of every month new schools should hold a ceremony of Confucian worship, and the Confucian classics should still be a major part of their curricula (Ichiko 1978). Nevertheless, in reality, Confucianism lost its significance as the state 
ideology and was no longer the basis of Chinese intellectual life (Schneider 1971).

The educational reforms, the expansion of the public sphere, and the formation of new elites in late imperial China together prepared a platform for the development of new thinking on China's culture and history. New Western ideas and practices were introduced into China through various channels. As early as the $1860 \mathrm{~s}$ the Qing reformers had opened a school of interpreters in Beijing, where courses on Western sciences and international laws were taught, and where Western books were translated into Chinese. Government-sponsored language schools were soon opened in Shanghai, Guangzhou, Fuzhou, and many other cities. Scholarreformers such as Kang Youwei 康有爲 (1858-1927), Liang Qichao 梁啟超 (1873-1929), and Yan Fu 嚴復 (1854-1921), who translated the works of Darwin, Huxley, Spencer, and Adam Smith into Chinese, wrote or translated books to promote Western social and political ideas. During his sixteen years of exile after the fiasco of the Hundred-Day Reform in 1898, Kang Youwei visited many museums, ancient ruins, monuments, and archaeological sites all over the World. In the process, Kang developed his own views on how China should preserve its own cultural heritage (Kang 1972). The Qing government also dispatched students and delegations of imperial court officials to study foreign practices in Japan and the West (Spence 1990: 245-246). Among them was the high official and art collector, Duanfang 端方 (1861-1911), who led a group of Qing officials touring the USA, Europe, and Japan from 1905 to 1906 (Lawton 1991: 5-11), during which he visited many world-famous museums. After his return to China, Duanfang proposed to establish public libraries, museums, zoos, and parks (gongyuan 公園) as part of the government's ongoing modernization efforts. 
An important idea that emerged from these activities was publicmindedness (Qin 2004: 140-142). Anti-Manchu nationalists such as Zhang Binglin 章㶧麟 (1868-1936) and Liang Qichao blamed China's weakness on the lack of national or public consciousness. In order to awaken the Chinese people, they urged that new social institutions and social values be advocated. Even the Qing government started to attend to the public needs. Public parks, public museums, and public libraries were introduced into China during this period. In 1906 the imperial delegation brought back from Germany various exotic animals as gifts to the Empress Dowager and put them in the eastern part of the imperial garden in the northwestern suburbs of Beijing. Renamed Wanshengyuan 萬牲園 (the Garden of Ten Thousands Animals), this zoo opened to the public in 1908 as part of the Empress Dowager Cixi's New Policies reforms - the Beijing Zoo is still located in the same place today. The reformer and entrepreneur Zhang Jian 張謇 (1853-1926) suggested to the Qing government that exhibition halls combining the functions of museum and library should be set up. But the government did not heed his suggestion. Zhang eventually established a museum at Nantong in Jiangsu in 1905 (Claypool 2005; Qin 2004: 143-160). This was the first successfully run public museum established by Chinese in China. In the spring of 1909, the Governor of Shandong, Yuan Shuxun 袁樹勛, was permitted by the Qing government to establish a provincial library in Shandong. One of its branches was the 'Shandong Antiquities Preservation Institute (Shandong jingshi baocunsuo 山東金石保存所)', the aim of which was to 'collect the old and new unearthed objects and the rubbings [of stone steles and shrine decorations]'. Its collection was put on exhibition and open to the public (Li 1993: 310).

The public consciousness and the process of introduction of new social values continued and was pushed to new levels during 
the New Culture Movement after the May Fourth movement in 1919, which further introduced new Western ideas such as 'science' and 'democracy'. The introduction of these new ideas and values promoted a re-evaluation of the Chinese past, including the material past (Bao 2000; Guo 2009).

\section{Western exploitation and the public awareness of cultural heritage}

In the same period, the plundering of ancient relics by Westerners provoked public and official attention to China's cultural heritage. The best-known cases were the sack of the imperial palaces in Beijing by the Allied Forces of the eight Western powers in 1900, ${ }^{5}$ the archaeological expeditions along the Silk Road, the removal of manuscripts from the Dunhuang caves by Aurel Stein (1862-1943) in 1907 and by Paul Pelliot (1878-1945) in 1908 (Hopkirk 1984), and the destruction of Buddhist sculptures at the cave-temple complexes of Tianlongshan, Xiangtangshan, and Longmen. Local warlords also robbed ancient tombs and sold objects to foreign and Chinese collectors. In fact, the majority of the Chinese artworks in Western collections were taken away from China during this period, which was termed by some as a 'Golden Age' for collecting Chinese art objects (Cohen 1992). The awareness that cultural treasures were being stripped from the country at last led to actions to stop it. Among the last ordinances of the moribund Qing, in 1909, was one that explicitly covered protection of cultural sites, namely the already mentioned Measures for the Protection of Ancient Sites. ${ }^{6}$ Issued by the newly established Ministry of Internal Affairs (Minzhengbu 民政部), the Measures marked the beginning of a legal framework and of the consciousness of the need to preserve the past from the exigencies of the times. 
Although no evidence points to a direct link between the depredations at Dunhuang and the 1909 ordinance, it was certainly not a mere coincidence. Western cultural imperialism in the late 19th- and early 20th-century raised Chinese public awareness of the need to protect the nation's cultural heritage. Although it is often said in Western writings that Stein 'removed' the manuscripts and paintings of the Dunhuang caves, or 'purchased' them from the local Taoist priest Wang Yuanlu (ca. 1849-1931) who was occupying some of the deserted Buddhist caves at the time, recent archival studies of Stein's diaries and documents at the Oxford University library have clearly shown that, during their 'secret transactions', both Stein and Wang were aware of the 'improper' nature of their activities. There is no question that Stein took advantage of the social turmoil in China at that time in order to get these ancient treasures (Wang 2007).

Although strictly speaking the legal status of the Dunhuang caves was not clear, Wang Yuanlu also did not have the right to 'sell' these ancient manuscripts. After the discovery of the library cave by Wang in 1900, local officials ordered that the cave be sealed and these manuscripts and paintings be protected in situ. In addition, following the Tang and the Ming legal codes, the Qing dynasty legal code stipulated that, if buried objects (i.e. ownerless property) were found on government or private land, the discoverer could own and use them. The code, however, also stated that if the finds were extraordinary objects (yichang zhi wu 異常之物), such as ancient vessels (guqi 古器), bells and tripods, talismans and seals that are different from the usual shape (i.e. those objects which should not be possessed in non-government circles [minjian 民間]), they should be handed over to the authorities within thirty days; the violators were to be punished with eighty blows with light sticks, and the discovered extraordinary objects were 
to be placed under government ownership (Tian \& Zheng 1999: 266). The Qing government did exactly this after Pelliot's display of some Dunhuang manuscripts in Beijing in 1909. The government ordered local officials at Dunhuang to protect and inventory manuscripts, steles, and sculpture, and commanded that Wang Yuanlu safeguard the manuscripts (Lin, Ning \& Luo 1992: 3; Rong 2001: 164-168).

Before his arrival at Beijing, Pelliot visited Duanfang, the then Manchu governor-general of Jiangnan, in Nanjing on June 8, 1909. Duanfang and his associate Miao Quansun (1844-1919) were aware of Pelliot's collection of the Dunhuang manuscripts, but without a clear understanding of the scale of the entire collection in the library cave. Informed of Pelliot's upcoming trip to Beijing, Luo Zhenyu and other Chinese scholars in Beijing approached him. The large scale of Pelliot's collection, the majority of which had already been shipped to France, stunned the Chinese scholars. ${ }^{7}$ With Pelliot's permission, Luo and his colleagues copied a list of contents of the documents that Pelliot had sent back; they also photographed eight documents and hand-copied one. ${ }^{8}$

To Chinese scholars, the most important news that Pelliot brought to light was that there were still 8,000 scrolls of manuscripts left in the library cave. Luo Zhenyu reported this to the Ministry of Education, and requested that the Ministry purchase the documents and ship them back to Beijing (Guan 2000: 481-487). On October 2, 1909, five days after Luo had met Pelliot, he sent a letter to the editor of the newspaper Current Affairs (Shiwu bao 時務報). Luo wrote:

'I have heard that there are still manuscripts left in the library cave. I am going to report this to the government authorities and ask them to send a telegraph immediately to Governor-general Mao of Shaanxi and Gansu. 
Although I am not sure whether the remaining documents are still there, if there is any left, I will try my best to push the government [to bring them back]' (Meng 2004).

On the following day, October 3, 1909, the Ministry of Education sent a telegram instructing Governor-general Mao Qingfan to: 'examine the books and documents in the Thousand Buddha's Caves and send them to the Ministry; to examine also the steles and sculptures; and to prohibit the sales of these antiquities to foreigners.' In 1910, the Ministry of Education ordered all the remains of the Dunuang manuscripts to be shipped to Beijing. Although many were lost and stolen in the process, approximately 8,662 scrolls were stored in the Capital Library (now the National Library in Beijing) (Guan 2000: 487). It is interesting to note that when the Ministry of Education ordered the governor of the Gansu Province to protect the Dunhuang materials, the same Ministry also purchased the manuscripts from Wang Yuanlu. ${ }^{10}$

\section{Measures for the Protection of Ancient Sites}

It was in the same year, 1909, that the Ministry of Internal Affairs drew up the 'Measures for the Protection of Ancient Sites'. Established in 1906, the Ministry of Internal Affairs was led by Prince Su Shanqi 善耆 (1866-1922), a prominent figure in late Qing politics. Consistent with routine bureaucratic procedures, the Measures were sent to the Emperor as a memorial for review on September 20,1909. They were published in the Shibao 時報 newspaper on October 22, one month after the imperial endorsement. ${ }^{11}$ The promulgation of the Measures in a widely circulated newspaper showed the interest in the subject on a public level, beyond the government. 
The preamble to the Measures clearly stated that they were drawn up in reaction to foreigners who had gone inland of China (neidi 内地) to buy antiques such as 'ancient steles, stone carvings, paintings and manuscripts, and stone sculptures' to take back to their own countries. It also stated: 'If we permit the outflow [of the antiques], not only is it not agreeable with the spirit of the ancient people, but it also damages the dignity of the nation'. The government's effort was inspired by the fear that China would lose its treasures and dignity as a modern nation in the World. The preamble continued:

'In every nation the scope of the items under protection as ancient sites ( $g u j i$ ) by their ministries of internal affairs is rather large: for examples, the ancient writings (i.e. hieroglyphs) on the Egyptian pyramids, the ancient sculptures of the Greek Temples, the ten-thousandmiles (li) long ancient highway of the Romans, and the excavated ancient city of Pompeii.

The preamble also stated that in these foreign countries:

'the old residencies and material remains belonged to the former sages, and some are related to history (lishi 歷史), and others are of artistic (meishu 美術) significance. No matter large or small, all were collected and treasured'.

The preamble continued:

'(in these nations) from the imperial household down to the commoners, and from metropolitan centres down to small towns, all have museums to store objects in order to show the achievement of the civilization'.

The Measures also made reference to the international laws for the protection of national cultural heritage. They stated that: 
'as a rule, during military conflicts, other countries cannot destroy [our cultural relics]. Those that have been destroyed in wars should be compensated. This has been written down in international laws (wanguo gongfa 萬國公法).

The language in the Measures matched almost exactly what had been written by the aforementioned entrepreneur Zhang Jian, who proposed that the Qing government establish a national museum: 'There is one great law to protect [the patrimony]. In times of military invasion, the people from other countries cannot take or destroy it. Those who destroy it can be forced to make reparations. This is called international law (wanguo gongfa)' (Claypool 2005: 570). The mention of international law in the Measures intended, on one hand, to condemn the past lootings by Westerners in China and to prevent further damage by foreign raiding. On the other hand, it reflected the intention to incorporate international law into the Chinese legal system. In 1863, William Alexander Parsons Martin (Chinese name: Ding Weiliang 丁韪良, 1827-1916), an American Presbyterian missionary to China, translated Henry Wheaton's (1785-1848) Elements of International Law into Chinese. The translation was commissioned by the Office for the Management of the Business of All Foreign Countries of the Qing central government and was published in 1864 (Wheaton 2000). To include wanguo gongfa in the first government legislation for cultural heritage protection, especially the mention of the protection of the enemy's cultural property in time of war, indicates that the Chinese government was aware not only of the recent development in international law but also that it could use it to benefit the interest of China. International agreements in relation to the protection of an enemy's cultural property in time of war appeared in the Hague Conventions 
of 1899 and 1907, in which the Qing government participated and which it ratified. Furthermore, it shows that the Chinese heritage conservation movement closely followed the international heritage conservation movement from the very beginning.

In addition to the short preamble, the Measures included two sections: the first, with six items, focused on the investigation and inventory; the other, with five items, focused on protection. The scope of investigation and inventory included stone carving and petroglyphs, stone sculpture, mural paintings and sculpture, tombs and shrines of the previous dynasties, former sages, famous persons, and excavated objects. These were all the standard items in the writings of traditional local gazetteers. On the one hand, the Measures had a strong connection to the traditional practice of antiquarianism that had been practiced in China for over one thousand years. For example, the emphasis was on collecting the rubbings of stone inscriptions, in the formats of naming, recording, and classification of cultural heritage, which all echoed the traditional gazetteer writing. Since the Southern Song dynasty (1127-1279), local officials or social elite had surveyed famous historical and literary figures and the sites associated with them, often from written sources rather than from site visits. The compilation of the lists of these items had become part of the routine of local gazetteer writing and the local practice in protecting cultural sites. In imperial China, as part of central government's administrative control, local officials were obliged to submit to the court an inventory of sites that were protected at the end of each year. Moreover, under the influence of antiquarianism in the Qing dynasty, scholar-official Bi Yuan 畢沅 (1730-1797), the then governor of Shaanxi, in 1776 compiled an illustrated list of the historical sites of Shaanxi, Guanzhong shengji tuzhi 關中勝跡圖誌. 
In this work, Bi Yuan established a set of measures to protect ancient sites: demarcating the boundaries (the four corners), erecting boundary stones and walls, leaving latitude ( $y u d i$ 餘地) in the outside of the walls (a 'buffer zone'), and designating personnel to manage the sites.

This type of social survey was the very technique that a modern national government used to collect objective and systematic information for governing (Lam 2011). In fact, the Measures specifically required local officials to go to the field to investigate, rather than submitting the old yearly bureaucratic memorandum. Another way in which the Measures went beyond the traditional practice was its expanded categories of protected sites. The Measures were specifically targeted at objects, monuments, and sites that related to the commoner, going beyond the usual categories of imperial mausoleums, ancient tombs (guxi lingqin 古昔陵寝), and temples and burials of former sages (xianxian cimu 先賢祠墓) which often appeared in the local and national gazetteers. Such departure from the old gazetteer surveys of ancient sites was very much influenced by foreign models. It is significant that the word ' $g u j i$ ' instead of more common word ' $g u w u$ ' was used here, because during this period ' $g u w u$ ' often referred to both movable objects and monuments and sites.

In summary, the 1909 Measures for the Protection of Ancient Sites not only connected to the traditional practice of valuing art collections as well as imperial and religious sites, but also set up the framework for the protection of public monuments and art collections (in contrast to the 'private' collections of the emperors and members of the elite). It recognized two of the three categories of values that have been often ascribed to cultural heritage in modern China: historic and artistic values (the third one being scientific). 
The second section of the Measures included specifications about relocating stone objects, establishing regulations for the making of rubbings from steles, and erecting signs in front of important tombs and shrines. One of the most significant concepts mentioned in the Measures was the protection of mural paintings and sculptures. The relevant part stated:

'The exquisite mural paintings and sculptures should be protected. No damage is allowed. No repainting is allowed on those blurred images, in order not to lose the original appearance (benlai mianmu 本來面目). Otherwise [if it is repainted], we would see nothing of the ancient fine art'.

This was quite a departure from the traditional way of preserving religious images, which often repainted blurred images afresh. Another important reason for establishing public museums at the provincial level was that they could become public institutions for accepting donations, displaying art treasures, and educating the people. On this the Measures stated: 'if treasures cannot be appreciated by everyone, how can we ask everyone to love and care for them in case of unfortunate events?' Thus, 'every provincial capital should establish a museum to collect, to categorize, and to store [art treasures]', so that those who wanted to donate could donate, and those who wanted to temporarily store their treasures could do so too. The Measures continued: ' $(\mathrm{t})$ hus all treasures in the world can be shared by everyone. This not only can avoid the harmfulness of the seclusion, but also obtain the benefit of preservation'. Although it is still uncertain where these new ideas came from, and how and by whom they were incorporated into this document, it is clear that the 1909 ordinance marked a new beginning in the national protection of cultural heritage. 


\section{Public ownership and the fate of the imperial property}

The Qing dynasty ended in 1911 with the abdication of the Last Emperor Puyi. This event would profoundly affect the consideration of what constituted 'the past', and one started seeing the transformation of private and imperial places and spaces into public ones - state legislation played an important role in this process.

The presidency of the newly founded Republic went from Sun Yat-sen (1866-1925) to Yuan Shikai (1859-1916), a former Qing military official, who negotiated for the Qing abdication and controlled the imperial army. Under the arrangements of the Articles of Favourable Treatment of the Great Qing Emperor after His Abdication, the Last Emperor and his close associates continued residing in the rear part of the Forbidden City until 1924, when the Last Emperor was expelled from it by the General Feng Yuxiang 馮玉祥 (1882-1948). As mentioned at the beginning of this chapter, the fate of the imperial property and collections was debated before and during this period.

Still living in the Forbidden City, the young Emperor Puyi held his title and was surrounded by the imperial household and a group of loyalists, some of them casting greedy eyes on the imperial collections still housed in the imperial residence. But with the imperial dynasty gone, places such as the Temple of Heaven and the Altar of Earth and Grain, in the suburbs of Beijing, became overgrown with weeds and littered with refuse; although the Summer Palaces in the west suburbs and the imperial ancestral temples within the Forbidden City remained well preserved. How the neglected properties should be managed, and who had the right to own and dispose of them, were hot issues among not only members of the imperial household and the Qing loyalists 
but also the officials of the new Republican government as well as scholars and the common people. In November 1914, the Institute for Exhibiting Antiquities (Guwu chenlie suo 古物陳列所) in the Wenhuadian and Wuyingdian Halls in the front part of the Forbidden City opened its gate to the public. The Institute was set up by the Ministry of Internal Affairs, under the leadership of Zhu Qiqian 朱啓鈐 (1872-1964), to take over the ancient relics in the imperial collections that were housed outside of Beijing, from Fengtian (i.e. Shenyang), the homeland of the Qing, and the imperial summer resort at Jehol (Chengde) (Hang 2005; Wang 2010).

As shown at the beginning of this chapter, to Wang Guowei who had become ultraconservative politically and served as the Emperor's Companion of the Southern Study - the controversies and disputes over the imperial treasures were more than just an issue of property rights. Wang was assisting in inventorying the palace treasures such as books, bronzes, porcelains, jades, and paintings at the time. In his aforementioned letter to Shen Jianshi and Ma Heng and the Archaeological Society at Beijing University, Wang went further to accuse his colleagues at the university of being unwise and unkind and lacking in courage:

'Not to study either the history of the palace collections or the Articles of Favourable Treatment is unwise. To be familiar with both and yet deliberately to say this is unkind. The Archaeological Society was against the Ministry of Internal Affairs' "Opinions on the draft of the laws on protection of ancient books, objects, and sites", but did not make any criticism of the Republican authority's illegal takeover of the ancient relics from the imperial family to establish the Institute for Exhibiting Antiquities; instead the Society slanders the imperial family; being as it is a case of "devouring the weak and spitting out the strong" is uncourageous' (Yuan \& Liu 1996: 432). 
Wang complained that by adopting the position as indicated in the manifesto, his colleagues at Beijing University ignored not only their legal duty as citizens of the Republic of China but also their sacred duty as independent scholars and their moral obligations as human beings. He continued:

'If you are still a national university founded by the Republic of China, it is most certainly your duty to comply with the Articles by which the Republic was created as well as with its laws regarding the protection of private property. Universities are the highest institutions of learning in the entire country, and you gentlemen also uphold scholarship as your responsibility. When you make statements, therefore, you ought not to speak carelessly. Scholarship is certainly one of the highest enterprises of the human race, but if it is conducted without the support of moral and legal principles, it surely cannot stand alone. To protect ancient objects is only one goal of scholarship, but if, for the sake of preserving antiquities, one violates fundamental rights recognized in both laws and morality, both state and society will disintegrate and where will scholarship be then?' (Yuan \& Liu 1996: 433)

As stated earlier, Wang forthwith severed all relationships with Beijing University.

Earlier on, on May 18, 1924, sensing the mounting political pressure, Wang Guowei had submitted a proposal to the young Emperor to use the imperial collections as a shield to protect the imperial family. In this proposal he suggested that a section of the Forbidden City should be opened as a Museum of the Imperial Household:

'Now I have a plan, which has the advantage of protecting the imperial family but is without any harm. I suggest 
that a part of the Forbidden City should be opened as a Museum of the Imperial Household, displaying the ancient vessels and calligraphies and paintings from the Imperial Household; let all the people, Chinese and foreign, have the opportunity to appreciate them.... Thus the Forbidden City will become a gathering-place of Chinese culture, and will also forge an important connection to the world cultures. In case these are military affairs in the Capital, all the counties will have the responsibility to protect it' (Yuan \& Liu 1996: 416-417).

Wang Guowei's suggestion certainly did not attract the attention of the young Emperor. Five months later, the Last Emperor was expelled from the Forbidden City, and the palace treasures, except for those that the Last Emperor smuggled out, were inventoried by the Committee on Affairs Related to the Qing Imperial Family, and became the bulk of the collections of the Palace Museum, opened to the public on October 10, 1925.

Meanwhile, other public museums opened. One such museum was the Institute for Exhibiting Antiquities, led by Zhu Qiqian, an important figure in the modernization of Beijing and the protection of its cultural heritage during the early Republican period. After spending his childhood with his diplomat stepfather in France, Zhu came back to China as a young man, and launched an official career, highly trusted by the presidents Yuan Shikai and Xu Shichang (1855-1939). Soon he became a powerful figure in the Beiyang government. Zhu served as the Minister of Internal Affairs and the president of the Municipal Council. He travelled frequently to Japan, France, England, and the USA, and was familiar with the Western-style municipal administration. He attempted to apply what he learned to the modern transformation of the city. He was also a strong advocate of building 
and renovating the capital's streets, gates, sewage system, and public transport. In June 1914, he initiated the establishment of the Municipal Council of Beijing (Jingdu shizheng gongsuo 京都 市政公所). Under his leadership, a public park was created in the deserted imperial Altar of Earth and Grain near the Tian'anmen in 1914. ${ }^{12}$ Zhu was also interested in traditional Chinese craftsmanship. In 1919 he discovered a Song dynasty copy of the architectural manual Yingzao fashi (營造法式); he collated it with different editions, and finally published the result in 1923.

One of Zhu's achievements in regard to the protection of cultural heritage was the promotion of technological development and the scientific uses of the past. In December 1913, the Ministry of Internal Affairs (neiwubu 内務部) issued the 'The Bylaws of the Institute for Exhibiting Antiquities' (Guwu chenliesuo zhangcheng 古物陳列所章程). ${ }^{13}$ In the preamble to these bylaws, Zhu Qiqian set forth the motivation for establishing the Institute:

'Those who study the ancient subjects use them [i.e. guwu, ancient relics] to discover theories and natural laws, to observe the process of natural evolution, to explore the ingenuity of creation and production, and to examine the historical changes in human affairs. All the countries in the East and West collected treasures and establish special institutions in order to show the prosperity of production and to promote the study of fine arts. They pay special attention to the protection of ancient objects, and endeavour to guard them without loss'.

This apparently was a great departure from the traditional antiquarian goal, using antiquities to verify the ancient historiography and to legitimize political power. Here the preservation of cultural heritage was not for personal pleasure but for social progress and 
the public good. The function of museums as educational organizations was considered to display technological advancement. This way of valuing the past was very different from the traditional ones. Zhu's approaches had been influenced by the ideas of progress and Darwinism, as well as industrial expositions in other parts of the World in the late 19th-and early 20th-century, in which technology, industrial production, and its products were emphasized.

Zhu Qiqian further stated that since individual scholars did not have enough resources to guard the nation's cultural treasures, it became the government's responsibility to collect and protect ancient objects. Thus, the first article in the bylaws stated that: 'the Institute for Exhibiting Antiquities is in charge of the preservation of ancient relics and was subordinated by the Ministry of Internal Affairs'. At the same time, the Committee for Promoting the Protection of Ancient Relics was established and affiliated with the Institute. Another important point in this document was the issues related to the ownership of the cultural heritage. Against the background of the government's attempt to restrict the sales of ancient antiquity to foreigners, the bylaws emphasized the public ownership of cultural property. Reflecting the vast foreign trade of Chinese antiquities during this period, the consideration of moveable objects was given most emphasis (see Cohen 1992).

\section{Nationalism and the scientific value of archaeological heritage}

The establishment of the Institute for Exhibiting Antiquities and the Palace Museum concluded the fate of the Qing imperial art collections and property. Except for those art objects taken by the Last Emperor and others - the majority of which ended up in 
Western museums - the imperial collections and property now belonged to the nation. However, the opening of art markets in the West and Japan for Chinese antiquities had taken a terrible toll on China's archaeological heritage. The most appalling incident was the warlord Sun Dianying's (1889-1947) rifling of the tombs of Emperor Qianlong and Empress Dowager Cixi in the Eastern Mausoleums near Zhunhua, Hebei province in May 1928. After reuniting China and moving its capital from Beijing to Nanjing in 1927, the Nationalist government, led by General Chiang Kai-shek (1887-1975), started vehement nationbuilding campaigns. The surge of nationalism and the interplay with academic politics prompted scholar-politicians such as Fu Sinian 傅斯年 (1896-1950) to use new, Western, scientific archaeology to fight with both regionalism and imperialism (Lai 1999). The Chinese government started to exert tighter control on foreign expeditions and on the removal of antiquities from China, and the legislation on cultural heritage developed. Governmental and private institutions were established to take care of the cultural heritage. One of Fu's weapons was the national legislation on the protection of cultural heritage. In 1930, under the promotion of Fu Sinian, Li Ji 李濟 (1896-1979), and Dong Zuobin 董作賓 (1895-1963), the Nationalist government issued the 'Law on the Preservation of Ancient Objects' (Guwu baocun $f a$ 古物保存法) (Li 1996: 87-90), which clearly articulated the state ownership of all archaeological artefacts, and established a registration system for the control of private collections and limited the circulation and antiques trade. This state ownership included the right of excavation and the right to grant excavation licenses. The 1930 law set up the basic framework for protecting archaeological heritage that is still at work in the People's Republic today. 


\section{Law on the Preservation of Ancient Objects}

From a historical point of view, as Wang Guowei remarked in relation to the legal status of the imperial collections, in China the right to hold property of underground archaeological heritage traditionally privileged land owners and finders. Since the Tang legal code (in Tanglü shuyi), which was subsequently adopted by the Ming and Qing legal codes, the objects excavated by the land owners on their own property had belonged to themselves. When objects were discovered in other people's property, the finder should split half of the value with the property owner. The 1930 Law on the Preservation of Ancient Objects radically changed this centuries-long practice. As Articles 2 and 7 state, all underground artifacts now came to belong to the state (Li 2013: 110-126):

'Article 2: For all ancient relics, except for those privately owned, the Central Committee on Protection of Ancient Relics (Zhongyang guwu baoguan weiyuanhui 中央古物 保存委員會, abbreviated as CCPAR) assigns an appropriate location and institution for protection'.

'Article 7: All ancient objects underground or exposed on the surface belong to the nation. When such objects are discovered, the discoverer bears the responsibility to report to the local administrative office, which then reports to the higher authorities. Under the guidance of the Ministry of Education, the Ministry of Internal Affairs, and the CCPAR, the discovered relics should be received and protected. The discoverer should be rewarded properly. Discovering without reporting, as well as attempting to hide ancient objects, will be treated as theft'.

Another feature of the 1930 law was a new, scientific definition of 'guwu': 
'Article 1: 'the term guwu in this law refers to all the ancient objects related to archaeology, history, paleontology, and other branches of scientific studies. The Central Committee on the Protection of Ancient Relics (CCPAR) defines the scope and category of guwu'.

The law also creates a new national organization in charge of ancient relics, the CCPAR.

Article 9: the CCPAR consists of 6 to 11 experts appointed by the State Council (xingzhengyuan), 2 representatives from the Ministry of Education and the Ministry of Internal Affairs, and a representative from each national museum'.

The law also established a registration system for the control of private collections (Articles 5 and 6) and limits the circulation and antiquity trade (Articles 6 and 13).

Furthermore, the state ownership came to include the right of excavation as well as the right to grant license for excavation:

'Article 8: the excavation of ancient relics should be conducted by academic institutions under the central or local government. The excavation project must be approved by the CCPAR, and licensed by the Ministry of Education and the Ministry of Internal Affairs. Those excavations without appropriate license are treated as thievery'.

'Article 10: If it is necessary for foreign academic institutions or experts to participate in the excavation, it should be approved by the CCPAR'.

Following this law, several supplementary regulations were issued: the so-called 'detailed regulations' (古物保存法施行 細則1931); the regulations on the organization of the CCPAR 
(中央古物保存委員會組織條例1932); the regulations on excavation of ancient relics (採掘古物規則1935); the regulations on the participation of foreign institutions or individuals in excavation (外國學術團體或私人參加掘採古物規則1935); and the regulations on certification for export of ancient relics (古物出 國護照規則1935).

The significance of the 1930 law and related regulations lay in its pioneering role in establishing a new scientific definition of ' $g u w u$ ', which connected the objects of the past directly to modern disciplines introduced from the West. This scientific approach to physical remains of the past was reflected in the new ways of collecting data, the emphasis on archaeological fieldwork, and the insistence on the recording of the context where the objects were found, instead of just seeking treasure. The establishment of a national committee on cultural heritage institutionalized the control of cultural heritage.

The background of the 1930 Law on the Preservation of Ancient Objects was the Yinxu excavation, which the newly established Institute of History and Philology of the Academia Sinica had been conducting from 1928 in Anyang, Henan Province, the site of the last capital of China's earliest dynasty, the Shang. Under the leadership of Fu Sinian and Li Ji, this excavation was in the beginning an international cooperation with the Freer Galley of Art in Washington DC. The excavations were, however, interrupted several times. The initial agreement between the Institute of History and Philology and the local warlord Feng Yuxiang who controlled Henan at the time, was established thanks to Feng's submission to the Nationalist government. In May of 1929, however, the soldiers protecting the staff of the Yinxu project suddenly withdrew from the site, as Feng Yuxiang had defied Chiang Kai-shek's ban on the 
assembling of local armies and now began a war against the central Nationalist government.

Under the circumstances, Li Ji's decision to ship some of the artefacts to Beijing seems very reasonable. Nevertheless, he was promptly accused by local people and the provincial authorities of violating the agreement reached between the Henan government and the Institute of History and Philology. The original provincial permission had no mention of this issue. Only later had He Rizhang 何日章 (1893-1979), director of the Henan Provincial Library (Dashan 2007), suggested to the provincial government that the Yinxu treasures should be exhibited in Kaifeng, the provincial capital. The local authority quickly endorsed his suggestion. When this request reached the institute, it provoked a vague response - the issue of ownership was negotiable; after all, the institute was devoted to research, not to the acquisition of artefacts.

In October 1929, He Rizhang informed Li Ji that the Henan authorities had decided to prohibit all digging at Yinxu by the Institute of History and Philology - the process of excavating the site was soon taken over by the Henan Museum of Ethnography. ${ }^{14}$ Both parties to the dispute timed their moves in accordance with the vicissitudes of the conflict between Chiang Kai-shek and Feng Yuxiang, and those who held the right to excavate Yinxu were those who held political sway.

Fu Sinian immediately began looking for ways to settle the dispute through political channels. He contacted Wu Zhihui 吳稚暉 (1865-1953), a senior member of the Nationalist party who had regular contact with Chiang Kai-shek. Through this trusted official, Chiang Kai-shek became convinced of the importance of compelling the Henan local government to cooperate with the 
Institute's project. Fu Sinian, Li Ji, and Dong Zuobin also campaigned for the national legislation on archaeological heritage. The result was the 1930 Law on the Preservation of Ancient Objects. Furthermore, in order to convince local people to see the Yinxu excavation as a national event, Fu Sinian lectured on the use of archaeological discoveries in reconstructing national history. However, the Institute of History and Philology did not resume the work at Yinxu until Feng Yuxiang's war was concluded and Chiang Kai-shek regained control over Henan.

On the international level, the issue of ownership of archaeological heritage was also the incentive to agreement and dispute. Although not explicitly stated, one of the Freer Gallery's goals for archaeological excavations in China was certainly to get new data and possibly objects from secure archaeological contexts. As associate curator of the Freer from 1922 to 1934, Carl W. Bishop (1881-1942) led several archaeological expeditions in China. In the late 1920s, Bishop invited Li Ji, who had just returned from Harvard after obtaining a Ph.D. degree in anthropology, to participate in archaeological cooperation. Li Ji was sensitive to the issues of Western exploitation of Chinese cultural relics. He asked Bishop about the ownership of artefacts excavated in China, to which Bishop responded rather patronizingly:

'Your touching upon the subject of removal of art objects from Chinese soil opens up a very large and important subject, with the most far reaching ramifications, and especially thorny through the vested interests - art dealers both Chinese and foreign - concerned. I have some very decided ideas in this regard, however - ideas which I feel pretty sure will meet with your warm approval and support. I have not yet thought these out to the point where I can put them adequately upon paper; but it seems to me that I am slowly working toward a solution 
that will be fair to all. The time was when the notion of the Powers returning any portion of the Boxer Indemnity funds would have been laughed at; yet the needed change of feeling has been brought about, and it has always given me the sincerest pleasure to know that the United States took a leading part in initiating this movement.

There are several possibilities concerning the future treatment of Chinese art objects. I believe a beginning has already been made in the return of these to Chinese possession. Here, doubtless, the question of ownership, both original and actual, would come up. Another possibility is that of sending abroad loan collections, to be exhibited in certain definite foreign institutions for a period of years. It is unfortunately too true that the real greatness of China - her achievements in the past and her vast potentialities for the future - have been obscured during the past few years by news of bandits, floods, famines, and civil disorder to an extent wholly beyond the facts. No nation to - day can live to itself alone; and I for one should like nothing better than to give all the aid in my power in the direction of placing China in a proper light, particularly before the people of the United States. ${ }^{15}$

Bishop stated that his mission was to reveal the real greatness of China' to the people of the United States, to advance 'true scientific research', and to bring about 'the best possible understanding between the peoples'. He assured Li Ji that 'you would be asked to do nothing which you might feel incompatible with your allegiance to the Republic of China.' ${ }^{16}$

Li Ji was satisfied with the answer, although he did not miss the vagueness of Bishop's response. With the rise of nationalist sentiment in China, the possibility of setting up a mutually beneficial cooperation disappeared. The Freer Gallery of Art withdrew from 
the Yinxu excavation in 1930. The vagueness in the original agreement between the gallery and Li Ji gave rise to a series of disputes over the purpose of the excavation and the treatment of the unearthed artefacts (Li 1996: 62-65). In a situation that mirrored the conflicts at Yinxu of nationalism versus localism, national archaeology had to do battle with imperialist greed. It is in the context of dealing with both regionalism and foreign imperialism on the ownership of Chinese antiquities that the 1930 law was legislated.

\section{Conclusion}

In this chapter, I have traced the process of the transformation of cultural property from imperial and mostly private possessions in late imperial China to public monuments and state-owned cultural heritage of the early Republic through the use of state legislations and administrative orders. Attempts at modernization in China were evident toward the end of the Qing dynasty, but they were feeble and had only a marginal impact on the physical protection of cultural heritage. After the abolishment of the old civil examination system, education reforms started in order to face the challenge of the West and to modernize the old society. New social institutions such as public museums and libraries and new social values were introduced. During a temporary break from tradition, most imperial monuments were ignored and abandoned. Facing the challenge of the Western powers, the older Confucian ideology declined, and a new modern Westerninfluenced state ideology was developed. The central government and social elites took a new look at China's cultural heritage. In 1909, the Qing government ordered the protection of ancient objects and monuments, and later ordered a national survey of existing ancient objects and monuments. 
In the meantime, Westerners' explorations and stealing of ancient relics from China had provoked Chinese scholars, the public, and the government to pay attention to their cultural heritage. Several officials suggested establishing museums in China. Under Zhu Qiqian's leadership, the Institute for Exhibiting Antiquities was set up in 1914; the imperial palace in Beijing finally opened to the public in 1925, and the National Museum of History opened in 1926. With the introduction of new disciplines from the West, such as modern history, archaeology, anthropology, and architectural history, the old cultural heritage acquired new scientific values and meaning.

It is important to note that Chinese conservation movements have been mainly promoted by the nation-state. The control of cultural heritage in modern China is viewed as part of the state sovereignty - it is a political issue first and foremost. In the first half of the last century, the need to maintain sovereignty was closely linked to the claim of state ownership of cultural heritage and to the efforts to prevent foreigners from stealing and exporting ancient relics overseas.

Although very different in its political ideology from the Nationalist government, the Communist government after 1949 adopted the basic system set up by the 1930 Law on the Preservation of Ancient Objects. The current legal framework is basically an elaboration of this old system. This legal framework is quite defensive (emphasizing state ownership), prescriptive, and conservative. It stresses the issue of ownership and control, and is far less clear about issues of management. Today, Chinese heritage conservation is in the midst of a historical change, a dramatic shift from a state-monopolized enterprise to a multiple-channelled social project that will proceed at three levels: the national, the local, and the international. This transition has presented many 
difficult issues and challenges, but at the same time, it also provides opportunities and hope.

\section{Notes}

${ }^{1}$ Cited from a telegram, dated 12 November 1923, in which the Educational Society of Hubei Province urged the Beijing government to stop the Qing imperial family from selling ancient artefacts: see Li 2013: 36-37.

2 The term 'heritage' was first institutionalized in the West in Britain in 1975: see Pai 2013: xv-xvi.

3 This legal framework was basically followed even after the Communists took over China in 1949, such as in the $1982 \mathrm{Cul}$ tural Relics Law. Not until recently - in the revision of the Cultural Relics Law in 2002 - did things begin to change, especially in terms of the relaxed regulation on the domestic art markets and the emphasis on the economic value of cultural heritage.

${ }^{4}$ For the 'self-strengthening movement', see Spence 1990: 216-224 and Kuo \& Liu 1978: 491-542.

${ }^{5}$ After the International Expedition crushed the Boxer Uprising and occupied Beijing, looting by Western troops began and was soon out of control. Wilbur J. Chamberlin (1866-1901) recorded the extraordinary scale of looting. See Chamberlin 1904, especially pages 100-107.

${ }^{6}$ Da Qing fagui daquan 大清法規大全 (The complete law and regulation of the Great Qing). 1972, Reprint 1910 Shanghai Zhengxueshe edition, Taipei: Hongye shuju, Minzhengbu, vol. 2; juan 15, 'Baocun guji.'

${ }^{7}$ For Pelliot's trip to Beijing, see Jiqing 2011.

${ }^{8}$ Luo Zhengyu's Dunhuang shishi yishu 敦煌石室遺書 (The remaining documents from Dunhuang's Cave Library) and Liusha fanggu ji 流沙訪古記 (Visiting antiquity in the shifting sands) were both published at the end of 1909.

9 'Xing Shan Gan zongdu qing chi chayan jianxi Qianfodong shuji jiebu bing zaoxiang gubei wu ling wairen goumai dian 行陝甘總督請飭查驗檢析千佛洞書籍解部並造像古碑無 
令外人購買電, Xuebu Guanbao 學部官報 (Ministry of Education Bulletin), October 1909, no. 104.

${ }^{10}$ Luo Zhenyu proposed that the Ministry of Education should buy the Dunhuang manuscripts, while others suggested that the Ministry could use its administrative power to seize the manuscripts. Luo Zhenyu insisted that because the Gansu province was poor, the Ministry should pay to obtain them. In the end, the Ministry paid 6000 liang of silver, but this money was embezzled by local officials and Wang Yuanlu only got 300 liang of silver, less than what he had received from Pelliot. In 1907, Stein paid about 200 liang of silver to Wang Yuanlu and took away 29 boxes of manuscripts. In 1908, Pelliot paid 500 liang of silver. See Xinjiang 2001: 167-168. For what exactly Stein paid Wang and how many manuscripts and paintings he obtained, see Wang 2007.

${ }^{11}$ Shibao, XT 1/9/9 (Oct. 22/1910), p. 5.

${ }^{12}$ It was first called 'Zhongyang gongyuan' (Central Park), and changed to 'Zhongshan gongyuan', named after Sun Yat-sen in 1928. Other parks include Beihai Park (North Sea) in the old Imperial city opened in 1925; the Altar of Heaven in 1918; the Jingzhao Park, based on Earth Altar (Ming) outside north city wall, in 1925 (years of neglect and abuse by soldiers stationed nearby had turned it into wasteland); and the South City Park (near the Altar of Agriculture; not associated with the cultural monument) in 1917. Summer Palace and residential quarters of the Forbidden City were added to the 'list of public spaces' in 1924. As the head of Beijing's Central Park Administration, Zhu Qiqian ruled that no buildings in the park could be demolished or renovated without its approval; the same rule applied to other parks later; but new buildings, new plantings, and new uses of the place were allowed (ergo, no attempt to maintain the integrity of the parks as historic places). What Zhu Qiqian did in the Central Park was, first, to preserve all the important imperial ritual structures of the Ming and Qing dynasties under the protection of the state; second, to protect the old trees in the park; third, to relocate several pillars and steles from the ruins 
of Yuanming yuan to the Central Park and to install the stone lions from the Song dynasty discovered near Beijing; fourth, to build new facilities to accommodate the function of this place as a public park, for example, public toilets and benches; and fifth to plant trees and flowers. See Shi 1998: 233-236.

${ }^{13}$ In 1948 the Institute for Exhibiting Antiquities merged with the Palace Museum.

${ }^{14}$ Under Feng Yuxiang's sponsorship, the Henan Provincial Museum was established in 1927. In May 1928, its name changed to 'Museum of Ethnography' in order to propagate 'the ideal of national and universal harmony'. In December 1930, it changed its name back to Henan Provincial Museum.

15 Carl Whiting Bishop Correspondence, dated March 23, 1925, in the Freer Gallery of Art records, Li Chi file, housed in the Smithsonian Institution Archives, Washington DC.

${ }^{16}$ Ibid.

\section{References}

Bao X 鮑小會 2000 Zhongguo xiandai wenwu baohu yishi de xingcheng 中國現代文物保護意識的形成. Wenbo, 文博 3: $75-80$.

Bi Y 畢沅 (1730-1797) 2004 Zhang P 張沛 (ed.) Guanzhong shengji tuzhi關中勝跡圖誌. Xi’an: San Qin chubanshe.

Bonner, J 1986 Wang Kuo-wei: An Intellectual Biography. Cambridge. MA: Harvard University Press.

Chamberlin, W J 1904 Ordered to China, Letters Written from China While under Commission from the New York Sun during the Boxer Uprising and the International Complications which Followed. London: Methuen.

Claypool, L 2005 Zhang Jian and China's First Museum. Journal of Asian Studies, 64 (3): 567-604.

Cohen, W I 1992 East Asian Art and Culture: A Study in International Relations. New York: Columbia University Press.

Guan X 關曉紅 2000 Wan Qing xuebu yanjiu 晚清學部研究. Guangzhou: Guangdong jiaoyu chubanshe. 
Guo X 郭璇 2009 Chengchuan yu jiaorong: Xifang wenming dui Zhongguo jindai wenhua yichan baohu de yingxiang 承傳與 交融: 西方文明對中國近代文化遺產保護的影響. Xin jian$z h u$ 新建築, 6: 73-76

Hang X 杭曉春 2005 Huihua ziyuan: you “micang” zouxiang “kaifang”繪畫資源: 由“秘藏”走向‘開放. Wenyi yanjiu 文藝 研究, 2: 118-127.

Hopkirk, P 1984 Foreign Devils on the Silk Road: The Search for the Lost Cities and Treasures of Chinese Central Asia. Amherst: University of Massachusetts Press.

$\mathrm{Hu}$ C 胡長明 2000 Guo Songtao dui xifang shehui gongyi wenhua shiye de kaocha 郭嵩壽對西方社會公益文化事業的考 察. In: Wang X 王曉天and Xu Y 胥亞 (eds.) Guo Songtao yu jindai Zhongguo duiwai kaifang 郭高壽與近代中國對外開 放. Changsha: Yuelu shushe.

Ichiko, C 1978 Political and institutional reform, 1901-1911. In Fairbank, J K (ed.) The Cambridge History of China, vol. 10, Late Ch'ing, 1800-1911. Cambridge: Cambridge University Press. pp. 376-383.

Kang Y 康有爲 1972 Baocun Zhongguo mingji guqi shuo 保存中 國名跡古器說. In: Kang W 康文佩 (ed.) Kang Nanhai (Youwei) xiansheng nianpu xubian 康南海有爲先生年譜續編. Taipei: Wenhai chubanshe. pp. 95-106.

Kuo, Ti-Y, and Liu, K-C 1978 Self-strengthening: the pursuit of Western technology. In: Fairbank, J. K. (ed.) The Cambridge History of China, vol. 10, Late Ch'ing, 1800-1911. Cambridge: Cambridge University Press. pp. 491-542.

Lai, G 1999 Digging Up China: Nationalism, Politics, and the Yinxu Excavations, 1928-1937', paper presented at a panel on 'Sciences of the Human: Classicism, Modernism, and Nationalism in Chinese Social Sciences, 1899-1937. In The Fifty-first Annual Meeting of the Association for Asian Studies, Boston, 13 March 1999.

Lawton, T 1991 A Time of Transition: Two Collectors of Chinese Art. Lawrence: Spencer Museum of Art and the University of Kansas. 
Li G 李光謨 1996 Chutou kaoguxuejia de zuji - Li Ji zhixue shengya suoji 鋤頭考古學家的足跡 - 李濟治學生涯瑣記. Beijing: Zhongguo renmin daxue chubanshe.

Li X 李曉東 1993 Zhongguo wenwuxue gailun 中國文物學概論. Shijiazhuang: Hebei renmin chubanshe.

Li X 李曉東 2013 Minguo wenwu fagui shiping 民國文物法規史 評. Beijing: Wenwu chubanshe.

Lin J 林家平 Ning Q 寧強, and Luo H 羅華慶 1992 Zhongguo Dunhuang xue shi 中國敦煌學史 (A history of Dunhuang studies). Beijing: Beijing yuyan xueyuan chubanshe.

Liu Y 劉寅生and Yuan Y 袁英光 (eds.) 1984 Wang Guowei quanji, shuxin 王國維全集書信. Beijing: Zhonghua shuju.

Meng X 孟宪实 2004 Boxihe, Luo Zhenyu yu Dunhuang xue zhi chushi 伯希和、罗振玉与敦煌学之初始. Duanhuang Tulufan yanjiu 敦煌吐魯番研究, 7: 1-12.

Naquin, S 2000 Peking: Temples and City Life, 1400-1900. Berkeley: University of California Press.

Pai, I 2013 Heritage Management in Korea and Japan: The Politics of Antiquity and Identity. Seattle: University of Washington Press. Qin S 2004 Cultural Modernity: The Nantong Model, 1890-1930. Stanford: Stanford University Press.

Ren D 任大山 2007 He Rizhang yu Henan bowuguan zaoqi jianshe 何日章與河南博物館早期建設. Zhongyuan wenwu 中原 文物, 3: 106-108.

Rong X 榮新江 2001 Dunhuangxue shiba jiang 敦煌學十八講. Beijing: Beijing daxue chubanshe.

Schneider, L A 1971 Ku Chieh-kang and China's New History: Nationalism and the Quest for Alternative Traditions. Berkeley: University of California Press.

Shi, M 1998 From Imperial Gardens to Public Parks: the Transformation in Urban Space in the Early Twentieth Century Beijing. Modern China, 24 (3): 219-254.

Spence, J. D. 1990. The Search for Modern China. New York: W.W. Norton \& Company.

Tian T 田濤 and Zheng Q 鄭秦 (eds.) 1999 Da Qing lüli 大清律 例. Beijing: Falü chubanshe. 
Tong L 2011 A Passion for Facts: Social Surveys and the Construction of the Chinese Nation-State, 1900-1949. Berkeley: University of California Press.

Wakeman, F Jr. 1975 The Fall of Imperial China. New York: Free Press. Wang C-h 2010 The Qing Imperial Collection Circa 1905-25: National Humiliation Heritage Preservation and Exhibition Culture. In: Wu H (ed.) Reinventing the Past: Archaism and Antiquarianism in Chinese Art and Visual Culture. Chicago: The Center for the Art of East Asia, University of Chicago. pp. 320-341.

Wang J 王冀青 20071907 nian Sitanyin yu Wang Yuanlu ji Dunhuang guanyuan zhijian de jiaowang 1907年斯坦因與王圓 祿及敦煌官員之間的交往. Dunhuangxue jikan 敦煌研究輯 刊, 3: 60-76.

Wang J 王冀青 2011 Boxihe 1907 nian Beijing zhi xing xiangguan riqi bianzheng 伯希和1907年北京之行相關日期讋 證.Dunhuangxue jikan 敦煌研究輯刊, 4: 139-144.

Wang R 汪榮祖 2006 Zouxiang shijie de cuozhe: Guo Songtao yu Dao Xian Tong Guang shidai 走向世界的挫折: 郭嵩濤與道 咸同光時代. Beijing: Zhonghua shuju.

Wheaton, H 2000 Huidun Wanguo gongfa惠頓萬國公法, translated by Ding Weiliang 丁韪良. Beijing: Zhongguo zhengfa daxue chubanshe.

Yuan Y 袁英光and Liu Y 劉寅生 1996 Wang Guowei nianpu changbian 王國維年譜長編. Tianjin: Tianjin renmin chubanshe. 